\begin{tabular}{|c|c|c|c|c|}
\hline JURNAL & VOLUME 1 & NOMOR 1 & HALAMAN 1-70 & $\begin{array}{r}\text { ISSN 2655-8823 }(p) \\
\text { ISSN - }(e)\end{array}$ \\
\hline
\end{tabular}

\title{
EKSISTENSI MASYARAKAT ADAT TERGERUS OLEH KEBUTUHAN ZAMAN

\author{
Studi Analisis Konflik Masyarakat Adat Sunda Wiwitan di Kuningan yang Terusir dari Tanah \\ Adatnya Sendiri dengan Teori Identitas
}

\author{
Rachel Farakhiyah \\ Mahasiswa Program Studi Kesejahteraan Sosial FISIP UNPAD \\ E-mail: rachelfrk23@gmail.com \\ Maulana Irfan \\ Dosen Program Studi Kesejahteraan Sosial FISIP UNPAD \\ E-mail: maulana.irfan@unpad.ac.id
}

\begin{abstract}
ABSTRAK
Pengakuan pemerintah terhadap hukum adat masih setengah hati. Padahal, eksistensi hukum adat memiliki landasan konstitusional yang kuat dalam Pasal 18B ayat (2) UUD 1945. Tubrukan antara proyeksi pembangunan dari pemerintah, kepentingan masyarakat umum, beserta hak ulayat dari masyarakat adat, telah menimbulkan gesekan yang sangat rentan akan timbulnya konflik. Seperti halnya yang memicu terjadinya konflik yang memanas di dalam masyarakat sunda wiwitan atas sengketa lahan. Yang mana perlakuan Jaka yang mengklaim tanah adat menjadi tanah milik pribadi sebagai bentuk pelanggaran hukum adat dan kemudian ditambah dengan putusan PN Kuningan yang memanangkan permintaan Jaka atas hak milih tanah adat seluas $224 \mathrm{~m}^{2}$. Putusan PN tersebut dinilai cacat hukum dan tidak memperhatikan asal usul sejarah. Maka hal tersebut menimbulkan berbagai aksi perlawanan dari pihak kubu masyarakat adat Sunda Wiwitan untuk berusaha memperoleh kembali haknya atas tanah adat mereka. Tujuan penulisan artikel ini yaitu untuk menjelaskan latarbelakang terjadinya konflik dan pemicu terjadinya konflik dengan menggunakan teori identitas yang nantinya dapat dirumuskan resolusi konflik yang efektif. Metode yang digunakan dalam penulisan artikel ini yaitu menggunakan studi litelatur yang diperoleh dari jurnal,buku, dan berbagai macam berita. Hingga saat ini konflik yang bergulir belum menemukan kejelasan karena belum terdapat resolusi konflik yang jelas dan masih sampai kepada tahap digagalkannya proses eksekusi tanah adat seluas $224 \mathrm{~m}^{2}$ oleh Pengadilan Negri Kuningan.
\end{abstract}

Kata Kunci : Sunda Wiwitan, sengketa lahan adat, kehilangan identitas adat, hak ulayat

\section{ABSTRACT}

Government recognition of customary law is still half-hearted. In fact, the existence of customary law has a strong constitutional foundation in Article $18 B$ paragraph (2) of the 1945 Constitution. Collisions between projected development from the government, the interests of the general public, along with customary rights from indigenous peoples, have created a very vulnerable friction in the emergence of conflict. As is the case that triggered a heated conflict in Sunda Wiwitan society over land disputes. Which is the treatment of Jaka who claimed customary land to be privately owned as a form of violation of customary law and then added with the Kuningan District Court decision to adopt Jaka's request for customary land rights of $225 \mathrm{~m} 2$. The Kuningan District Court ruling was deemed legally flawed and did not pay attention to the origin of history. So this caused various acts of resistance from the sides of the Sunda Wiwitan indigenous people to try to regain their rights to their customary lands. The purpose of writing this article is to explain the background of the occurrence of the conflict and the trigger for the occurrence of conflict by using identity theory which can later be formulated effective conflict resolution. The method used in writing this article is to use litelatur studies obtained from journals, books, and various kinds of news. Until now the rolling conflict has not yet found clarity because there is no clear conflict resolution and is still up to the stage where the process of execution of customary land of $225 \mathrm{~m} 2$ was thwarted by the Kuningan District Court.

Keywords: Sunda Wiwitan, customary land disputes, loss of indigenous identity, communal rights 


\section{PENDAHULUAN}

Eksistensi masyarakat adat merupakan suatu gambaran jelas dari negara plural. Eksistensi tersebut tidak dinilai melalui seberapa banyaknya masyarakat adat yang mendiami negara tersebut, namun hal tersebut dilihat melalui perbedaan frekuensi antar masyarakat dengan masyarakat adat yang saling memegang teguh prinsip hidup satu sama lain, yang jelas memiliki banyak perbedaan yang mencolok. Kekhasan dari tiap masyarakat adat merupakan harga tertinggi dari sebuah identitas yang dibangun oleh masyarakat adat itu sendiri, dan dengan beragam bentuk yang autentik. Misalnya, Dayak dengan tradisi Kanayatn dan bentuk penguburannya berupa Selokng, ataupun Sunda Wiwitan dengan prinsip Undak Usuk/bertatanan dalam kekeluargaan.

Perbedaan prinsip/hukum yang terjadi di antara masyarakat adat dengan masyarakat pada umumnya menghadirkan perbedaan kepentingan didalamnya. Lalu, perbedaan tersebut dapat melahirkan polarisasi \& fragmentasi social yang terjadi pada bangsa, yang selanjutnya dapat menciptakan konflik akibat adanya gesekan antara kepentingankepentingan tersebut. Dalam tatanan teori konflik, terdapat salah satu teori yang memberikan pemahaman mengenai bagaimana hubungan masyarakat dapat menimbulkan konflik. Teori ini menyatakan bahwa konflik disebabkan oleh adanya polarisasi \& fragmentasi sosial, serta ketidakpercayaan dan permusuhan yang terus terjadi diantara kelompok - kelompok masyarakat yang berbeda atau majemuk. Teori ini membantu menjelaskan adanya kemajemukan dan ketegangan social yang sudah barang tentu terjadi karena perbedaan dan pertentangan kepentingan, prinsip dan kehendak yang ada.

Perseteruan terkait gesekan kepentingan antara masyarakat, mampu menghadirkan terenggutnya hak dari masing-masing pihak yang berseteru. Konflik dapat bermula dari adanya hak yang direnggut ataupun keadilan yang tidak dapat dikukuhkan, yang mana berakhir kepada sengketa dan merujuk kepada terdapat konflik - konflik lainnya yang bermunculan. Percabangan dari satu konflik ke konflik lainnya memicu durasi konflik yang akan terus bertambah lama dan menumpuk, seiring berjalannya waktu. Untuk itulah peninjauan kembali akar dari permasalahan atau konflik, seringkali ditemukan beberapa gesekan kepentingan yang menyangkut masalah ekonomi, social dan budaya.

Tergerusnya identitas dari suatu kelompok oleh zaman, dapat bermula dari konflik kecil antar-masyarakat yang bercabang menjadi konflik dengan isu sebesar "eksistensi budaya yang tergerus oleh kebutuhan masyarakat di zaman kemajuan". Hal ini pula yang terjadi pada masyarakat adat Sunda Wiwitan yang berada di Kabupaten Kuningan Provinsi Jawa Barat. Konflik yang bermula dari berbagai macam bentuk diskiriminasi yang dari negara ataupun masyarakat umum. Yaitu, diskriminasi pada tidak diakuinya keyakinan leluhur/aliran kepercayaan sunda wiwitan. Selain itu ditambah lagi banyak tanah leluhur yang merupakan situs budaya yang sudah hilang, beralih fungsi dan berpindah menjadi milik pemerintah. Hal tersebut terasa sejak ditetatpkannya Undang-Undnag Pokok Agraria Tahun 1960.

Bentuk diskriminasi ini adalah sebagai awal rasa kekecewaan yang dirasakan oleh masyarakat adat sunda wiwitan kepada pemerintah, yang belum menjadi konflik terbuka masih laten. Kemudian ketika ada kasus akan diadakannya penggusuran tanah adat yang dimilikinya oleh Pengadilan Negeri atas kemenangan yang diterima Jaka Rumantaka memicu konflik laten itu menjadi konflik terbuka (manifest). Akhirnya rasa amarah dan kekecewaan masyarakat adat semakin memanas, yang berujung pada berbagai aksi penolakan dan berakhir ricuh 
Terlepas dari sengketa lahan tersebut, konflik ini kemudian berkembang menjadi konflik vertical antara masyarakat Sunda Wiwitan dengan Penguasa (pemerintah dan aparat) yang dapat dikatakan sebagai ajang pemudaran eksistensi dari masyarakat Sunda Wiwitan, yang memiliki semangat perjuangan untuk mempertahankan eksistensi peninggalan adat, beserta eksistensi masyarakatnya sendiri.

\section{TINJAUAN PUSTAKA Pengertian Konflik}

Konflik adalah hubungan antara dua pihak atau lebih ( individu atau kelompok ) yang memiliki atau yang merasa memiliki, sasaran-sasaran yang tidak sejalan. Konflik adalah suatu kenyataan hidup, yang tidak terhindarkan dan bersifat kreatif. Konflik terjadi ketika tujuan masyarkat tidak sejalan dan munculnya ketidakseimbangan diantara hubungan-hubungan sub sistem yang ada di masyarakat (Fisher, 2001,p.4). Jadi intinya di dalam masyarakat akan selalu terjadi konflik yang disebabkan karena setiap individu itu unik dan tidak sama yang memungkikan benturan kepentingan dan perenggutan hak salah satu pihak. Konflik itu sendiri ada yang destruktif maupun yang konstruktif.

\section{Teori Konflik}

Teori konflik yang digunakan untuk menganalisis konflik ini yaitu dengan menggunakan konflik identitas. Konflik identitas berasumsi bahwa konflik disebabkan karena identitas yang terancam, yaitu sering berakar pada hilangnya sesuatu atau penderitaan di masa lalu yang tidak diselesaikan. Sasaran yang ingin dicapai teori ini yaitu :

a. melalui fasilitasi lokakarya dan dialog antar pihak yang mengalami konflik mereka diharapkan dapat mengidentifikasi ancaman dan ketakutan yang mereka rasakan dan untuk membangun empati dan rekonsiliasi diantara mereka.

b. Meraih kesepakatan bersama yang mengakui identitas pokok semua pihak. (Fisher,2001,p.8)

\section{Jenis Konflik}

Berikut empat bentuk konflik sosial menurut Simon Fisher, yaitu sebagai berikut (fisher,2001,p.5):

a. Tanpa Konflik, menggambarkan situasi yang relatif stabil, hubunganhubungan antarkelompok bisa saling memenuhi dan berlangsung damai. Dalam hal ini, bukan berarti bahwa konflik sama sekali tidak terjadi, melainkanada beberapa kemungkinan yang mendukung situasi tanpa konflik.

b. Konflik Laten, suatu keadaan yang di dalamnya terdapat banyak persoalan sifat tersembunyi, dan perlu diangkat ke permukaan agar bisa ditangani.

c. Konflik Terbuka, situasi ketika konflik sosial telah muncul ke permukaan, berakar dalam (deep rooted), dan sangat nyata, sehingga diperlukan berbagai tindakan untuk mengatasi akar penyebab dan berbagai dampaknya.

d. Konflik di Permukaan, umumnya tidak berakar dalam dan muncul hanya karena kesalahpahaman mengenai hal-hal tertentu, yang dapat diatasi dengan meningkatkan komunikasi dan dialog antarpihak.

\section{Dinamika konflik}

Menurut fisher tahapan dinamika konflik meliputi prakonflik, konfrontasi, krisis, akibat dan pasca konflik(fisher, 2000,p.19):

a. Prakonflik adalah priode pada saat terdapat suatu ketidaksesuaian sasaran diantara dua pihak atau lebih, sehingga timbul konflik. 
b. Konfrontasi memperlihatkan suatu tahap pada saat konflik mulai terbuka.

c. Krisis adalah puncak konflik. Tahap ketika konflik pecah menjadi bentuk aksi- aksi kekerasan yang dilakukan secara intens dan massal.

d. Akibat, merupakan hasil dari krisis.

\section{METODE RISET}

Dalam penulisan artikel ini menggunakan metode penulisan studi literatur. Studi literatur adalah mencari referensi teori yang relefan dengan kasus atau permasalahan yang ditemukan. Maka dari itu sumber dan jenis data-data yang digunakan dalam penyusunan artikel ini berasal dari berbagai literatur kepustakaan yang berkaitan dengan permasalahan yang dibahas. Beberapa jenis referensi utama yang digunakan adalah artikel ilmiah yang bersumber dari internet jurnal ilmiah edisi cetak maupun edisi online, buku dan situs - situs di internet. jenis data yang diperoleh variatif, bersifat kualitatif maupun kuantitatif.

Studi literatur di sini mampu menguatkan dasar referensi teori. Output yang didapakan dari studi literatur terkait masyarakat adat sunda wiwitan, eksistensi masyarakat adat sunda wiwitan di Kuningan, dan konflik yang terjadi di dalam masyarakatnya. Dalam menganalisis data yaitu setelah semua data yang dibutuhkan terkumpul diseleksi dan diurutkan kembali sesuai topik pembahasan dalam artikel. Kemudian dilakukan penyusunan artikel berdasarkan data yang telah dipersiapkan secara logis dan sistematis. Teknis analisis data bersifat deskriptif argumentatif. Sedangkan kesimpulan didapatkan setelah merujuk kembali pada rumusan masalah . tujuan penulisan serta pembahasan.

\section{HASIL PENELITIAN}

Kornologis Terjadinya Konflik pada Masyarakat Sunda Wiwitan Cigugur, Kuningan

\section{Prakonflik}

Mempertahankan diri menjadi penghayat sunda wiwitan itu bukan suatu hal yang mudah, karena ada berbagai macam bentuk diskiriminasi yang ia terima dari pemerintah daerah ataupun masyarakat umum. Yang pertama diskriminasi pada keyakinan leluhur/aliran kepercayaan sunda wiwitan yaitu ketika ditanya mengenai identitas agama oleh masyarakat umum ataupun untuk kepentingan administrasi oleh petugas pemerintahan, mereka menganggap remeh agama kepercayaan sunda wiwitan dan tidak mengakuinya. Jadi ketika pembuatan KTP, mereka tidak dapat menuliskan agama kepercayaan sunda wiwitan di dalam kolom agama, alhasil yang membuat para petugas terkadang sembarangan menulis agama yang hanya diakui resmi oleh pemerintah, karena tidak dapat dikosongkan. Sama halnya ketika pendaftaran sekolah,pembuatan akte kelahiran, daftar kerja dan lainnya. Selain itu ditambah lagi banyak tanah leluhur yang merupakan situs budaya yang sudah hilang, beralih fungsi dan berpindah menjadi milik pemerintah. Hal tersebut terasa sejak ditetatpkannya Undang-Undnag Pokok Agraria Tahun 1960.

Bentuk diskriminasi ini adalah sebagai awal rasa kekecewaan yang dirasakan oleh masyarakat adat sunda wiwitan kepada pemerintah, yang belum menjadi konflik terbuka atau masih berbentuk konflik laten.

Sekitar tahun 1980-an, tanah adat seluas $224 \mathrm{M}^{2}$ diberikan kepada pihak lain oleh Pangeran JatiKusuma, yaitu keluarga Kusnadi dan Mimin untuk dijadikan rumah adat dan cagar budaya. Namun Jaka Rumantaka merasa bahwa masyarakat adat yang bukan keturunan sesepuh adat tidak memiliki hak untuk mengklaim tanah tersebut sebagai tanah adat. Jaka merasa bahwa tanah yang seluas $224 \mathrm{M}^{2}$ adalah tanah peninggalan warisan ibunya yaitu Siti Djenar yang merupakan anak dari ketua adat terdahulu yaitu Tedjabuana, maka hanya dia 
yang berhak untuk memanfaatkan tanah tersebut untuk apapun. Jaka tidak ingin ada pihak lain yang memanfaatkan tanah tersebut karena ia ingin membuat rumah makan di atas tanah tersebut sebagai cara untuk untuk menafkahi keturunan ibunya yaitu Siti Djenar ( anak dari Tedja Buana, sesepuh sunda wiwitan setelah Madrais).

Namun sebenarnya sudah jelas tercantum di dalam manuskrip yang dibuat oleh Pak Madrais sebagai ketua adat pertama/ pendiri AKUR (Kesatuan Masyarakat Adat Karuhun Urang) bahwa keturunan tidak mendapatkan pembagian waris. Adapun tanah-tanah dan bangunan memang diperuntukkan untuk masyarakat adat guna melestarikan ajaran kebudayaan untuk kepentingan bangsa. Tetapi pihak Jaka Rumantaka tidak menghiraukan hal tersebut.

1. Konfrontasi

Pada tahun 2008 Raden Jaka Rumantaka melayangkan gugatan ke Pengadilan Negeri Kuningan, untuk menggungat Kusnadi dan K.Mimin. Setelah melalui berbagai proses sidang akhirnya pada tahun 2012, Mahkamah Agung melalui putusan peninjauan kembali memenangkan Jaka sebagai pemilik tanah itu. Hal ini dikarenakan Jaka telah memiliki kekuatan hukum mengikat yaitu keterangan ahli waris dan sertifikat kepemilikan tanah, sehingga secara yuridis - normatif, objek sengketa dalam gugatan dapat dieksekusi, kecuali ada hal-hal tertentu yang dapat menunda atau menangguhkan eksekusi.

Dipicu dari kemenangan Jaka atas kepemilikan tanah adat seluas $224 \mathrm{M}^{2}$ dan akan dilakukannya eksekusi oleh pihak Pengadilan Negeri menimbulkan perlawanan dari masyarakat Adat Sunda Wiwitan yang akan mempejuangkan kepemilikan atas tanah adatnya. Hal ini dikarenakan terdapat cacat hukum yang mana masyarakat penghayat Sunda Wiwitan mengklaim, sejak 1960 leluhur warga adat termasuk Pangeran Tedja Buana tidak membuat sertifikat tanah karena menyadari seluruh tanah adat adalah milik komunal, yang tidak dapat dijual kepada pihak mana pun dan Masyarakat Sunda Wiwitan menganggap putusan tersebut tidak mempertimbangkan amanat leluhur dari aspek sejarah, sosial, dan budaya.

Maka dari itu pada tahun 2015 Jatikusuma sebagai pihak dari Masyarakat adat Sunda Wiwitan melayangkan gugatan ke Pengadilan Negeri Kuningan, namun karena pihak MA dan Pengadilan Negeri meminggirkan legitimasi hukum adat dan lebih menggunakan kerangka hukum waris jadi gugatan yang diajukan oleh masyarakat adat gagal dan dimenangkan oleh Jaka Rumantaka yang berarti tetap memiliki hak atas tanah dan akan segera langsung dilakukan eksekusi oleh pihak Pengadilan Negeri.

2. Krisis

Setelah terjadi 2 kali usaha eksekusi tanah yaitu 14 dan 20 Agustus 2017 yang dilakukan oleh Pengadilan Negri, akhirnya terjadi Konflik puncaknya pada eksekusi tanah tanggal 24 Agustus 2017. Pada hari itu, Petugas Juru sita Pengadilan Negeri Kuningan telah dikawal oleh 450 polisi. Namun, kedatangan mereka dihadang oleh 300-an masyarakat adat Sunda Wiwitan. Warga melakukan aksi tidur di jalan oleh para wanita yang lengkap mengenakan pakaian adat putih berselendang batik. Setelah aksi tidur di jalan, masyarakat adat pun melakukan aksi bakar ban bekas.

Kericuhan terjadi setelah warga adat Sunda Wiwitan yang didukung berbagai elemen massa sendiri yang melakukan aksi menolak eksekusi tanah adat seluas sekitar 224 meter persegi terlibat adu dorong dengan petugas keamanan. 
Kericuhan pertama terjadi saat ibu-ibu warga adat Sunda Wiwitan yang menyanyikan lagu-lagu kebangsaan sambil menangis terlibat saling dorong dengan polisi wanita (polwan) Polres Kuningan yang menjaga pelaksanaan eksekusi. Kericuhan juga terjadi antara petugas pengamanan yang terdiri dari polisi dan Satpol PP Kabupaten Kuningan dengan massa aksi, yang terdiri dari warga adat, LSM GMBI, mahasiswa, dan warga umum. Mereka terlibat saling dorong hingga adu pukul. Akibat dari konflik dan kericuhan yang memuncak pada saat proses akan melakukan eksekusi tanah adat, seorang petugas polisi, dua petugas Satpol PP, dan seorang warga adat dilaporkan terluka, dan langsung dibawa ke rumah sakit yang berjarak dekat dengan lokasi kericuhan.

3. Akibat

Setelah kejadian pada tanggal 24 Agustus 2017 yang menimbulkan korban, pada akhirnya Kedua belah pihak akhirnya melakukan gencatan senjata. Juru Sita Pengadilan Negeri Kuningan langsung menyampaikan berita acara bahwa proses eksekusi dinyatakan selesai dan gagal. Pemohon (Jaka) dapat melanjutkan kasus, namun harus melakukan pengajuan dari awal lagi.

\section{Negara 'Setengah Hati' Dalam Mengakui Hukum Adat Sunda Wiwitan}

Konflik pertanahan yang menimpa komunitas Sunda Wiwitan ini semakin menambah 'daftar hitam' diskriminasi negara terhadap hak-hak komunitas adat. Seperti dikeluhkan oleh salah satu pemuka adat Sunda Wiwitan, dalam konflik pertanahan yang menimpa mereka, pengadilan melihat sengketa dengan kerangka hukum waris kolonial, bukan dengan kerangka hukum adat lokal. Dengan kata lain, pengakuan pemerintah terhadap hukum adat masih setengah hati.
Laporan dari KOMNAS HAM menyebutkan, bahwa konflik agrarian yang berawal dari sengketa kepentingan umum telah menjadi salah satu bentuk konflik social-ekonomi yang sering terjadi di Indonesia, bahkan terdapat trend peningkatan jumlah dan kompleksitas konflik yang semakin meningkat. Tragedy berdarah akibat konflik agrarian yang berdimensi pelanggaran HAM datang silih berganti, dan sebagian besar yang menjadi korban adalah komunitas masyarakat hukum adat dalam mempertahankan hak ulayatnya.

Selanjutnya, hak ulayat kembali dipertanyakan seiring dengan adanya sentiment yang menyatakan bahwa eksistensinya dapat menghambat pembangunan untuk tujuan kepentingan umum. Kepentingan umum itu sendiri menurut UU No. 2 Tahun 2012 tentang Pengadaan Tanah Bagi Pembangunan Untuk Kepentingan Umum diartikan sebagai kepentingan bangsa, negara dan masyarakat yang harus diwujudkan oleh pemerintah dan digunakan sebesar-besarnya untuk kemakmuran rakyat. Hal ini pun menimbulkan tubrukan konsep antara kepentingan umum dengan hukum tanah ulayat pada masyarakat adat yang memiliki hukum adat beserta kepentingannya sendiri. Padahal, eksistensi hukum adat memiliki landasan konstitusional yang kuat dalam Pasal 18B ayat (2) UUD 1945. Hukum adat itu sendiri merupakan salah satu sub-sistem hukum nasional - selain hukum Islam dan hukum Barat-yang diakui dalam bingkai pluralisme hukum nasional sebagaimana diatur dalam butir ke-2 TAP MPR No. IV/MPR/1999 tentang GBHN Tahun 19992004.

Selain itu, hak-hak komunal masyarakat adat juga diakui dalam UU No. 5 Tahun 1960 tentang Peraturan Dasar Pokok-Pokok Agraria (UUPA), yang lebih dikenal dengan istilah "hak ulayat". Meskipun demikian, secara faktual hak-hak konstitusional 
masyarakat adat kerap 'dikebiri' oleh pemerintah. Tubrukan antara proyeksi pembangunan dari pemerintah, kepentingan masyarakat umum, beserta hak ulayat dari masyarakat adat, telah menimbulkan gesekan yang sangat rentan akan timbulnya konflik.

Ironi yang terjadi pada benturan antara berbagai kepentingan tersebut pun juga dirasakan oleh masyarakat Sunda Wiwitan. Bukan hanya sengketa lahan di Cigugur saja, sampai saat ini pun masyarakat Sunda Wiwitan masih kewalahan dalam mempertahankan warisan leluhur yang telah diamanahkan oleh penerusnya melalui manuskrip/Nawala warisan leluhur, khususnya warisan berupa tanah leluhur yang merupakan situs budaya dari masyarakat Sunda Wiwitan. Salah satu contoh dari kewalahan tersebut ialah patungan yang diadakan oleh masyarakat Sunda Wiwitan di Kuningan untuk membeli kembali tanah leluhur mereka seluas satu hektar. Situs tersebut terletak di Kawasan Curug Goong dan masih terdapat 2 hektar tanah yang belum bisa terbeli.Pembelian situs Curug Goong ini merupakan salah satu cara agar masyarakat adat mempertahankan peninggalan leluhur Sunda Wiwitan, sehingga anak cucu mereka mengetahui, lalu dijadikan sebagai wilayah komunal. Namun sampai saat ini, bukannya memberikan bantuan, pemerintah malah semakin mempersulit keadaan dengan dibuatnya banyak peraturan yang menutup akses untuk masyarakat Sunda Wiwitan mendapatkan haknya kembali.

\section{PEMBAHASAN}

\section{Penyebab Konflik}

Melalui Teori Penyebab Konflik identitas, dapat dikaitkan bahwa konflik yang terjadi pada masyarakat Sunda Wiwitan disebabkan oleh adanya identitas yang terancam yang seringkali berakar pada hilangnya sesuatu atau penderitaan di masa lalu yang tidak terselesaikan. Pemilihan teori ini dikaitkan dengan rekam jejak diskriminasi yang terjadi pada masyarakat Sunda Wiwitan oleh negara selama beberapa tahun kebelakang, hingga saat ini. Asumsi bahwa kasus pengambilan lahan adat oleh Jaka dengan masyarakat AKUR hanyalah sebuah bentuk pemicu dari konflik yang sudah dipendam lama terkait lahan adat yang banyak yang menghilang tanpa adanya kepastian hak ulayat oleh negara dan pihak penguasa, merupakan bentuk dukungan dari kecocokan Teori Identitas yang menyebabkan terjadinya konflik. Karena identitas dari masyarakat yang semakin termarjinalkan oleh system beserta hukum yang berlaku saat ini, tanpa mempertimbangkan hukum adat yang sudah mengikat masyarakat Sunda Wiwitan secara lebih serius, memberikan efek keberlangsungan konflik yang kokoh dan berputar dalam tatanan eksistensi atau identitas dari adat Sunda Wiwitan di Indonesia.

Selain pada pihak AKUR, Jaka Rumantaka selaku pewaris lahan pun memiliki penderitaan masa lalu yang tidak terbantahkan. Factor pemicu konflik pada Jaka ialah kekecewaan atas tanah ibunya yang selama ini dikuasai oleh keluarga Jatikusuma, yang mana hal tersebut berefek pada kehilangan martabat beserta nama baik dari ibunya yang juga merupakan keturunan dari leluhur Sunda Wiwitan, dengan menjadi pengemis untuk mengisi perut anak-anaknya.

\section{Tipe Konflik}

Konflik yang terjadi diantara masyarakat Sunda Wiwitan dengan pihak pro eksekusi lahan dapat dikatakan sebagai konflik terbuka (konflik manifest), yang mana memiliki akar penyebab yang nyata dan dengan berbagai efek didalamnya. Konflik ini memberikan duduk perkara atau akar permasalahan yang lebih konkrit ketimbang sebatas perselisihan sengketa lahan antara masyarakat dengan Jaka saja, yang mana konflik ini memberikan akar dari banyaknya 
bentuk diskriminasi yang diberikan kepada hak-hak masyarakat Sunda Wiwitan dalam proses pengadilan, ataupun sebelum terjadinya sengketa lahan bergulir. Hal ini didasari dari aksi terencana yang dilakukan oleh masyarakat AKUR dalam menuntut keadilan pada eksekusi lahan, lalu disusul dengan patungan uang untuk pengambilan kembali lahan yang hilang menjadi wilayah komunal dari masyarakat Sunda Wiwitan. Pergerakan dari masyarakat AKUR ini didasari oleh urgensitas eksistensi masyarakat Sunda Wiwitan yang tergerus oleh beragam kebutuhan zaman dan kepentingan dari pihak penguasa, terhadap situs yang dilestarikan oleh leluhur dari masyarakat Sunda Wiwitan. Bentuk keterbukaan dari konflik ini pun dapat diambil melalu pergerakan terorganisir beserta perencanaan aksi yang mampu untuk menggagalkan eksekusi tersebut, yang merupakan sebuah respon atas gerakan dari Jaka dan kecacatan hukum, serta pengesampingan hak ulayat yang dilakukan oleh PN Kuningan beserta petinggi lainnya. Konflik ini dapat dikatakan sebagai konflik yang terlihat jelas melalui perseteruan yang panas sewaktu diadakan persidangan juga.

\section{Aktor Dalam Konflik}

Banyak aktor yang terlibat di dalam konflik sengketa lahan masyarakat adat sunda wiwitan di Kuningan, yaitu Jaka Rumantaka salah satu keturunan Tedjabuwana sebagai tokoh utama yang memicu terjadinya konflik. Aktor-aktor yang mendukung dan berpihak pada Jaka yaitu ; Badan Pertahanan Nasional sebagai pengadministrasi pertanahan berperan mengeluarkan surat titel atas tanah dan mengadministrasikannya; Lurah Kantor Cigugur sebagai pimpinan tertinggi di kelurahan berperan mengeluarkan keterangan ahli waris bagi Raden Jaka Rukmantaka; Camat Kecamatan Cigugur sebagai atasan Lurah Cigugur berperan dalam administrasi pertanahan. Sedangkan pihak yang kontra dan melakukan perlawanan, yaitu Jatikusuma sebagai Kepala Adat AKUR Sunda wiwitan, Masyarakat Adat Sunda Wiwitan dan didukung oleh LSM GMBI

\section{Dampak Konflik}

Dampak yang disebabkan akibat konflik perebutan tanah adat diantara Jaka dengan masyarakat sunda wiwitan menyebabkan dampak yaitu :

a. Dampak Negatif :

- Membuat Masyarakat Adat Sunda Wiwitan terancam terusir dari tanah adatnya sendiri. Membuat Masyarakat adat harus patungan membeli tanah adatnya sendiri demi mempertahankannya.

- Masyarakat adat Sunda Wiwitan mengalami perlakuan diskriminatif dalam kehidupan sosial.

- Masyarakat adat Sunda Wiwitan kehilangan cagar budaya dan tempat untuk melangsungkan upacara adat.

- Hilangnya kekuatan dan kedudukan hukum adat masyarakat sunda wiwitan di dalam kehidupan masyarakat dan tidak diakui oleh pemerintah.

b. Dampak Positif :

- Meningkatnya solidaritas antar masyarakat adat Sunda Wiwitan dengan pertimbangan kesadaran kolektif masyarakat adat akan hak adat dan tanah adat yang terampas.

- Memunculkan empati pada kelompok atau perseorangan yang mengulurkan tangan untuk menyelesaikan konflik sengketan tanah adat ini yaitu seperti LSM GMBI, dan mahasiswa. 
- Kesadaran taat hukum dan pergerakan yang prosedural serta sistematis yang timbul pada masyarakat adat Sunda Wiwitan.

- Aspirasi yang disalurkan oleh masyarakat Sunda Wiwitan mampu diserap oleh masyarakat umum dan pemerintah dengan penyebar-luasan kabar di berbagai media nasional yang ekspansif.

\section{Resolusi Konflik}

Konflik sengketa lahan yang bergulir diantara masyarakat adat Sunda Wiwitan dengan kubu Jaka Rumantaka sebenarnya belum terselesaikan dengan tuntas, karena baru sampai kepada digagalkannya proses eksekusi tanah adat. Meskipun upaya resolusi konflik sudah dilakukan melalui jalur litigasi ( melalui proses hukum) tetapi ternyata jalur hukum itu tidak netral dan memihak pihak Jaka , sedangkan usaha audiensi dan pertemuan /mediasi dua kubu ini untuk membicarakan duduk perkara tidak juga terlaksana hal tersebut yang membuat kasus ini tidak juga menemukan titik terang penyelesainnya. Meskipun saat ini kondisi sudah mulai mereda karena eksekusi tanah digagalkan tetapi sewaktu-waktu konflik dapat memanas kembali jika, pihak jaka melakukan gugatan kembali meskipun harus kembali dari awal.

Melalui Teori Identitas pada penyebab konflik, maka resolusi konflik yang dapat ditempuh dalam menyelesaikan konflik masyarakat Sunda Wiwitan dengan Jaka beserta pihak pendukung lainnya yang dapat dikaitkan sebagai pihak penguasa/negara, ialah berupa terdapat tindakan oleh pihak ketiga yang tidak terkait/netral (seperti KOMNAS HAM) untuk memfasilitasi diadakannya lokakarya dan dialog antara pihak pro (Jaka, BPN, Lurah Kantor Cigugur, Camat Kecamatan Cigugur) dengan pihak kontra (Kepala Adat AKUR Sunda wiwitan,
Masyarakat Adat Sunda Wiwitan, LSM GMBI dan LSM Lainnya) dengan agenda pengidentifikasian ancaman tergerusnya identitas masyarakat Sunda Wiwitan dengan identitas tanah milik Tedjabuwana, Kepastian perlindungan hukum yang jelas dan adil antar-pihak konflik pemaparan ketakutan yang antar-pihak rasakan agar mendorong terbangunnya empati dan rekonsiliasi antar-pihak, dan terakhir agenda pengawasan HAM terkait perjalanan konflik tersebut. Jadi intinya perlu adanya pihak ketiga yang netral terlibat sebagai advokator dan mediator yang mendampingi terus selama konflik berlangsung. Dari, pihak pemerintah daerah pun harus mulai dapat mengakui keberadaan dari hukum adat dan hak ulayat dari masyaakat Sunda wiwitan, sehingga proses implementasi kebijakan lebih jelas dan adil.

Sasaran yang ingin diraih dari resolusi ini ialah tercapainya kesepakan bersama antara pihak pro eksekusi dengan kontra eksekusi, yang mana masing-masing harus ditinjau melalui kebutuhan identitas pokok semua pihak.

\section{KESIMPULAN DAN SARAN Kesimpulan}

Konflik yang terjalin diantara masyarakat adat Sunda Wiwitan dengan pihak Jaka Rumantaka merupakan konflik manifest/ terbuka karena sangat jelas akar permasalahannya akar permasalahan jadi sebenarnya tidak sebatas perselisihan sengketa lahan antara masyarakat dengan Jaka saja, yang mana konflik ini memberikan akar dari banyaknya bentuk diskriminasi yang diberikan kepada hak-hak masyarakat Sunda Wiwitan dalam proses pengadilan, ataupun sebelum terjadinya sengketa lahan bergulir yang dilakukan oleh negara dan sistem pemerintahan. sepertihalnya yang dijelaskan di dalam teori identitas.

Bahkan perlu dicatat bahwa secara logika, keberhasilan perjuangan puluhan 
masyarakat AKUR yang termobilisasi untuk melakukan unjuk rasa dan banyak memakan korban luka, tidaklah sebanding dengan penyelesaian kegagalan eksekusi yang dapat dilayangkan gugatan kembali oleh Jaka, tanpa adanya kepastian apakah konflik ini akan terulang kembali atau tidak. Seperti yang diungkapkan dalam tatanan teori, bahwa konflik hanya mampu untuk diredam, tidak dihilangkan

Hal ini disebabkan karena belum mampu mengelola konflik, resolusi konflik yang sudah dilakukan selama ini pun hanya formalitas semata, jadi meskipun dilakukan melalui jalur litigasi tetap merugikan salah satu pihak yaitu masyarakat Sunda Wiwitan, karena ternyata haknya dan hukum-hukum adatnya sudah benar-benar tidak diperhatikan lagi. Pemerintah dan aparat penegak hukum seakan-akan cacat hukum karena tidak mementingkan hak ulayat dan hukum adat, padahal sudah jelas-jelas diatur landasan konstitusional yang kuat dalam Pasal 18B ayat (2) UUD 1945. Konflik ini harus segera diselesaikan karena jika tidak masyarakat adat Sunda Wiwitan akan semakin terusir dari tanah adatnya sendiri, dan eksistensinya semakin memudar. Maka dari itu hal ini menjadi tugas semua pihak, tidak hanya bagi pemerintah saja tetapi pihak lain yang juga ikut terlibat dan memerlukan jalur lain di luar pengadilan.

\section{Saran}

Perjuangan dari masyarakat AKUR ini seakan-akan menyiratkan sebuah pesan kepada negara, yang seharusnya mampu untuk bertindak adil dengan memperhitungkan hak-hak yang dimiliki oleh masyarakat Sunda Wiwitan. Aparat Pemerintah harus lebih mempertimbangkan hukum adat dan mendengarkan faktor sosiokultural dalam pengambilan keputusan. Untuk memperkuat posisi masyarakat kiranya harus memperkuat nilai/norma yang selama ini dianut. Penyelesaian konflik dengan menggunakan pihak ketiga seperti komnas ham perlu dilakukan juga agar keputusan yang diperoleh tidak memihak dan dapat mendampingi masyarakat sunda wiwitan selama proses penyelesaian konflik. Hal yang dapat dilakukan oleh komnas HAM ataupun LSM/NGO seperti LBH yaitu Misalnya untuk memfasilitasi diadakannya lokakarya dan dialog antara pihak pro dengan pihak kontra,melakukan proses advokasi dan menjadi mediator. Dengan usaha tersebut diharapkan dapat menemukan titik terang dari permaslahan ini.

\section{DAFTAR PUSTAKA}

Agus,Andi aco .2017. Eksistensi Masyarakat Adat Dalam Kerangka Hukum Indonesia Jurnal Sosilsasi Pendidikan Sosiologi UNM.Vol.4 No.1

Fisher,S.,Ludin,.J.,Williams,S.,Abdi,D.,Smit h,R.,\&William,S.(2001). Mengelola konflik: Keterampilan \& Strategi untuk Bertindak.Kartikasari SN,MD Tapilatu,R Maharani,dan $\mathrm{DN}$

Rini,Penerjemah:Kartikasari

SN,editor.Jakarta(ID):The British Council.

Gamin,\&Fati Lazira.2017. Penyelesaian Sengketa Ruang Hidup Masyarakat Sunda Wiwitan di Kabupaten Kuningan.JSPH.Volume 2,nomor $1 \mathrm{Hal}$ 1-8.

Husen Alting, Dinamika Hukum dalam Pengakuan dan Perlindungan Hak Masyarakat Hukum Adat Atas Tanah (Yogyakarta: LaksBang PRESSindo, 2010), hlm. 30.

Mudjiono.2004.Eksistensi Hak Ulayat dalam Pembangunan Daerah.Jurnal Hukum. Vol.11 No 25 Hal 152-166.

Tim Pembela Kesatuan Masyarakat AKUR Sunda Wiwitan (2017,mei 30). Siaran Pers Tim Pembela Kesatuan Masyarakat Adat Sunda Wiwitan (Bagian 1). Retrieved desembe 6,2018, from Http://www.Findglocal.com/ID/Jakarta/6 


\begin{tabular}{|c|c|c|c|c|}
\hline $\begin{array}{c}\text { JURNAL } \\
\text { KOLABORASI RESOLUSI KONFLIK }\end{array}$ & VOLUME 1 & NOMOR 1 & HALAMAN 1-70 & $\begin{array}{c}\text { ISSN 2655-8823 }(p) \\
\text { ISSN - }(e)\end{array}$ \\
\hline
\end{tabular}

68695293269863/Perhimpunan-

Pembela-Masyarkat- Adat-Nusantara.

https://kbr.id/berita/10-

2017/membentengi_tanah_sunda_wiwita

$\mathrm{n} / 93130 . \mathrm{html}$, yang diakses pada tanggal

11 Desember 2018.

https://www.cnnindonesia.com/nasional/201

70823191041-20-236802/sunda-

wiwitan-tersingkir-dari-tanah-sendiri,

yang diakes 11 Desember 2018

https://ahmadsamantho.wordpress.com/2016

/10/14/mengenal-lebih-dekat-ageman-

sunda-wiwitan/, yang diakses 11

Desember 2018

https://regional.kompas.com/read/2017/09/0

4/05353971/warga-adat-sunda-wiwitan-

patungan-beli-tanah-leluhur,yang diakses

11 Desember 2018

https://id.wikipedia.org/wiki/Tanah_ulayat,y ang diakses 11 Desember 2018

https://www.academia.edu/14085902/Dilem atika_Pencabutan_Hak_Ulayat_Untuk Kepentingan_Umum_diIndonesia

https://www.merdeka.com/peristiwa/perjuan gan-warga-sunda-wiwitan-di kuninganpertahankan-tanah-adat.html, diakses 11 Desember 2018 